\title{
Nature, life and mind. An essay on the essence
}

\author{
S. Marinković ${ }^{1}$, S. Pajić ${ }^{2}$, O. Tomić ${ }^{3}$ \\ ${ }^{1}$ Department of Neuroanatomy and Gross Anatomy, Institute of Anatomy, Faculty of Medicine, Belgrade, Serbia \\ ${ }^{2}$ Department of Art History, Faculty of Philology and Arts, University of Kragujevac, Kragujevac, Serbia \\ ${ }^{3}$ Department of Art History, Department of Fine Art, Faculty of Art and Design, Megatrend University, Belgrade, Serbia
}

[Received 22 December 2014; Accepted 6 January 2015]

Background: Our long-standing scientific work and love to the fine art and nature for many years succeeded in making a unifying description of the three domains, at a time when a high specialisation in science, and even in art, has neglected the necessary entirety.

Materials and methods: Some neurons of a rat cerebral cortex were labelled with true blue and photographed under a fluorescent microscope. A monkey brain was sectioned in the axial plane. Several slices of the human motor cortex were stained with cresyl violet. A cerebral hemisphere image was modified, and another image was created in Adobe Photoshop.

Results: Some 10 billion years after the Big Bang life appeared on the Earth, reaching its peak with development of the brain. The humans started exploration of the local nature to survive, and the universe for psychological support. The antique philosophers Leucippes, Democritus and Heraclitus were the first to create a unifying atomic theory and to suggest the eternal movement of the matter. Newton and Kepler explained the movement of the celestial objects, whereas Einstein, Planck, Bohr, Hubbel, Howking and many others connected the quantum physics and elementary forces with the essence of the universe. Leonardo da Vinci, and later many others as well, united science and art. Philosophers and mathematicians created the phenomena which do not exist in nature.

Conclusions: Nature designed the human brain, more complex than the universe itself, which in turn created millions of the artworks and scientific discoveries. The might of the mind in some domains overcomes the power of nature. (Folia Morphol 2015; 74, 3: 273-282)

Key words: brain, evolution, fine art, music, nature, science, universe

\section{INTRODUCTION}

Nature, including the universe, life and human mind, especially science, philosophy and art phenomena, are the interconnected and overlapping domains. They have formed a unity from the very beginning which will continue to the very end.

\section{THE SKY}

The ancient civilisations, fascinated by the night sky, but also frightened by its dark mystery, chose 12 constellations as the sign of zodiac to predict their own destiny and the coming great events in their society or on Earth [23]. The Chinese bound the sky and earth into a "yang" and "yin" entity, along with all pairs of opposites in the universe. The Egyptians, Mesopotamians, Greeks and Romans ascended their greatest divinities into the sky, expecting them to provide light and warmth, to ensure food, to control the world and to prevent the chaotic effects of darkness. The Egyptian pyramids, aligned towards the pole star, and British Stonehenge, showing among others the direction of the summer solstice, are grandiose

Address for correspondence: Dr S. Marinković, Institute of Anatomy, Faculty of Medicine, University of Belgrade, Subotić 4/2, 11000 Belgrade, Serbia, tel: +381-11-2645958, fax: +381-11-2686172, e-mail: mocamarinkovic@med.bg.ac.rs 
monuments devoted to religion and astronomy [11]. The 6 thousand stars visible in the darkness by the naked eye, mostly concentrated in a luminous band arching across the sky and sprinkled out like drops of milk from a woman's breasts, as painted on a Tintoretto's canvas, were named "Via Lactea", i.e. the Milky Way [1, 42].

Unlike their ancient ancestors, contemporary people watch the night sky to admire cosmic beauty and to dream, as if they are listening to a Chopin's nocturne or Rimbaud's poem "My Stars in the Sky", or watching the whirls of "The Starry Night" painted by van Gogh, the whirlpools of Descartes' "Celestial Vortices", a radial work "Starry Sky for the Queen of the Night" created by Schinkel, the pastoral plot of "A Midsummer Night's Dream" by Shakespeare, or star travel in the movie "2001: A Space Odyssey" directed by Kubrick $[11,28,41]$. The senior author of this essay, being a neuroscientist and a great nature and art lover, finds the stars similar to the cortical neurons of the brain labelled with a blue fluorescent dye (Fig. 1).

It is fascinating that billions of galaxies, many of them containing billions of stars and planets, numerous quasars, pulsars, black holes, nebulae and cosmic clouds, all in constant movement and cyclical changes, fill an immense space billions of light-years crossways [42]. According to Einstein's theory of relativity, the universe is organised in a 4-dimension space-time, with space and time changing by intensity of gravity and the speed of a moving body, as was metaphorically depicted on the surrealistic canvas "Searching for the Fourth Dimension" by Salvador Dalí, on a laser installation by Nam June Paik, and on the sculpture "Master of the Universe" by Richard Deacon $[10,28]$.

\section{MATTER, FORCES AND UNIVERSE}

The visible matter which occupies, to our surprise, only $0.5 \%$ of the composition of the universe, is made up of a few main elementary particles, i.e. the negatively charged electrons (leptons) orbiting an atomic nucleus at various energy levels at nearly the speed of light, and quarks which build up the positively charged protons and the neutral neutrons within the nucleus $[10,43]$. The particles are bound among themselves by 4 basic forces, that is, the weak nuclear forces, strong nuclear forces, gravity, and electromagnetic forces, including light with its photons that travel at the highest speed in the universe

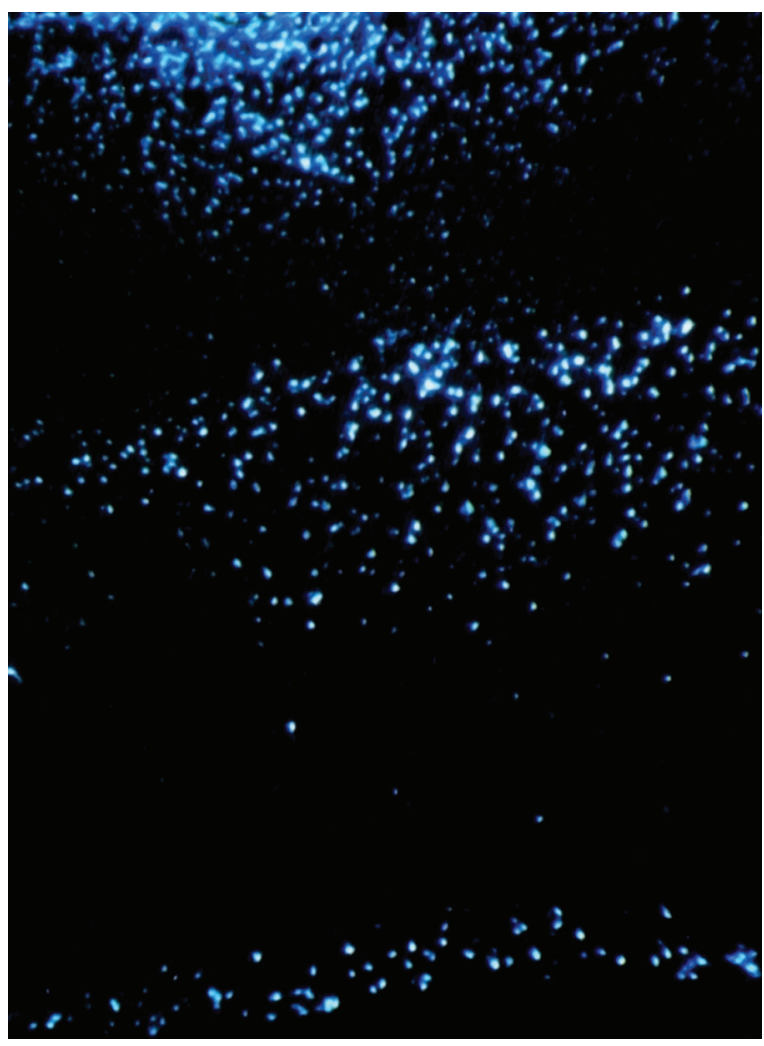

Figure 1. Cerebral micro-universe. An image of the rat neocortex to show certain groups of the cortical neurons labelled with true blue fluorescent dye.

(about 186,000 miles per second). Photons, which are both particles and waves, actually belong to the force particles. All the main particles and their bounding forces often make a perfect unity, which inspired the mentioned artist Dalí to paint the "Intra-Atomic Equilibrium of a Swan's Feather". Finally, the "empty" interstellar and intergalactic space is occupied by dark matter $(26.5 \%)$ and dark energy $(73 \%)$, whose repulsive force overcomes gravitational force, thus causing the universe to expand.

Matter and energy, interconnected by the ingenious equation " $\mathrm{E}=\mathrm{mc}^{2}$ " of Einstein and by a "yang-yin" unity of opposites (ordinary matter-dark matter, gravitation-dark energy, matter-antimatter, positive-negative electric and magnetic poles, creation-destruction), are the essence of nature, from the miniature subatomic level to the giant clusters of galaxies, from a singular particles annihilation to the grandiose and unthinkable supernovae explosions [42].

Forces of nature influence our planet as well, causing its rotation around a north-south axis and orbiting the Sun, according to Newton's and Kepler's laws, along with the accompanied Moon which sta- 
bilises its axis and produces tides [10]. High pressure of the inner melted rocks sometimes causes volcanic eruptions, the movement of adjacent rock masses of tectonic plates produces earthquakes, and even formed mountains in the past, and several types of surface erosion also give their contribution to modelling the Earth landscapes.

\section{THE MIRACLE OF LIFE}

Hundreds of composers wrote pastorals, many thousands of painters and poets artistically glorified the Earth landscapes, but virtually only those decorated by a miracle of nature-life, a dynamic, energy producing, self-maintaining, self-controlling and self-reproducing system, always in interaction with its surroundings [4]. Although based on universal principles, life is yet a new quality which is more complicated than the galaxies themselves. Only several dozens of the main elementary particles, forces and processes, including the nuclear fusion in the stars (i.e. $\mathrm{H}+\mathrm{H} \rightarrow \mathrm{He}+$ energy), build, organise and keep the universe together [42]. On the other hand, hundreds of chemical reactions and physical processes take place in a single living unit every minute. This is equally true for microscopic living particles, such as bacteria, and for each cell in the huge body of the orcas [4].

\section{The pre-eonic life}

Nature started the evolution of life perhaps some 3.9 billion years ago using atoms and molecules of hydrogen $\left(\mathrm{H}_{2}\right)$, carbon $(\mathrm{C})$, nitrogen $\left(\mathrm{N}_{2}\right)$, oxygen $\left(\mathrm{O}_{2}\right)$, helium ( $\mathrm{He}$ ) and a few other elements which form almost $99 \%$ of the universe and about $96 \%$ of the present-day living matter. At that time, certain compounds from the primordial atmosphere, under the influence of ultraviolet and infrared radiation, formed the first organic molecules in a watery milieu [4]. They interacted among themselves for millions of years to create phospholipids eventually which formed plasma membranes, as well as the aggregates of certain organic monomers inside.

The following million years were spent for polymers formation and their simple replication. Crucial progress was achieved when short strands of RNA were formed, and later on larger RNA molecules and a double helix of the DNA, capable of self-replication and control of protein synthesis and chemical reactions in a closed system [21]. The DNA spiral molecule with the sequences of nucleotides, known as genes, became the essence of the living world, which progressively enabled the evolution of more and more complex creatures $[4,21]$.

\section{Indestructible life}

There is an amazing diversity of life which has colonised almost every part of Earth [4]. Some organisms were so adapted to tolerate air temperatures of $-70^{\circ} \mathrm{C}$, yet thermophile archeas can live at temperatures over $100^{\circ} \mathrm{C}$ in thermal springs. Halophiles thrive in very salty places, some others - in highly acidic or alkaline water. Chemoautotrophs obtain energy from inorganic chemicals, e.g. hydrogen $\left(\mathrm{H}_{2}\right)$, hydrogen sulphide $\left(\mathrm{H}_{2} \mathrm{~S}\right)$, elemental sulphur $(\mathrm{S})$ or even iron $(\mathrm{Fe})$. Some organisms live in deserts with not a single rain drop for years, whereas certain archeas, bacteria and animals survive in the ocean darkness at over $3 \mathrm{~km}$ depth. Many prokaryotes, algae and all plants use solar energy to produce from carbon dioxide and water, in the Calvin cycle during photosynthesis, important organic compounds, for instance, the monosaccharide glucose $\left(6 \mathrm{CO}_{2}+6 \mathrm{H}_{2} \mathrm{O}+\right.$ photons $\left.\rightarrow \mathrm{C}_{6} \mathrm{H}_{12} \mathrm{O}_{6}\right)$.

Certain prokaryotes convert nitrogen $\left(\mathrm{N}_{2}\right)$ into nitrates and nitrites helping the plant supply, some others accumulate heavy metals and certain poisons, including arsenic, from contaminated water or soil, and many prokaryotes and protists decompose organic substances [4]. Certain fungi may also degrade organic compounds, as well as many toxic substances and even plastic. Sunflowers may absorb radioactive metals and manage to survive in spite of radiation. All those organisms clean nature, enable the recycling of chemical elements, and even help us make bread, cheese, beer, wine and vinegar.

\section{Nature and life unity}

There is a permanent interaction among the living world, the Earth and cosmos [4]. Thus, primordial microorganisms, especially Cyanobacteria, some algae and plants later, due to their photosynthesis, enriched the atmosphere of Earth with oxygen, which enabled animals to appear. The Cyanobacteria colonies of today changed the colour of many lakes, some sorts of lichens sporadically occupied areas of several quarter miles across, sea corals created thousands of islands, whereas microorganisms and plants inhabited almost the entire Earth.

In order to interact with nature, living creatures developed during evolution special senses for detecting most of the segments of the electromagnetic 
spectrum and other types of energy [4, 10]. Thus, the photoreceptors in the retina may register each single photon of visible light, whereas in some animals they may detect ultraviolet rays [26]. Mechanosensory receptors in the body, as well as in the cochlea and the vestibular organs of the inner ear, may register pressure, vibrations, sound waves, and gravity, respectively. Migrating birds possess in their skull and the neurons of the brain small particles of magnetite, which enable them the orientation during long flights using the lines of the Earth magnetic field. Chemoreceptors in the nasal and oral cavity may register thousands of chemical substances in a very small amount. Specialised organs close to the nostrils of vipers react to the infrared radiation. Certain animals, e.g. the platypus, have electric receptors to detect the electric field of its prey. Some other animals, particularly fishes, developed special bioelectric organs to capture prey and to defend themselves. Thanks to some of those senses, but also to their mighty minds, human beings have altered landscapes all over the planet, even created new ones in the domain of land art [11].

Nature made the conditions for millions of species to develop and to enjoy life [4]. On the other hand, earthquakes, volcanic eruptions and similar events, sometimes drastically influence the survival of the living creatures and the landscape appearance. A huge asteroid, born in the solar system, struck the Earth some 65 million years ago and caused extinction of over $50 \%$ of genera in the living world. The universe sends us perpetual cosmic rays, radiation from all segments of the electromagnetic spectrum and, perhaps, some extraterrestrial messages.

Out of these cataclysmic events, the organisms can survive practically in any type of environment, and can use many different kinds of substances to provide energy. All these data, along with the corresponding universal principles and statistical probabilities, have convinced us that extraterrestrial life must exist, most likely on millions of planets throughout the universe (Fig. 2). (Recently, a huge infrared telescope was launched to search for $\mathrm{H}_{2} \mathrm{O}, \mathrm{CO}, \mathrm{CO}_{2}, \mathrm{CH}_{4}$, and similar precursors of life in the universe.) It is another question which substances, chemical reactions and physical processes they use to build themselves and to produce energy, what they look like and how intelligent they are.

Nevertheless, we are disappointed by the fact that we would probably never be able to visit the

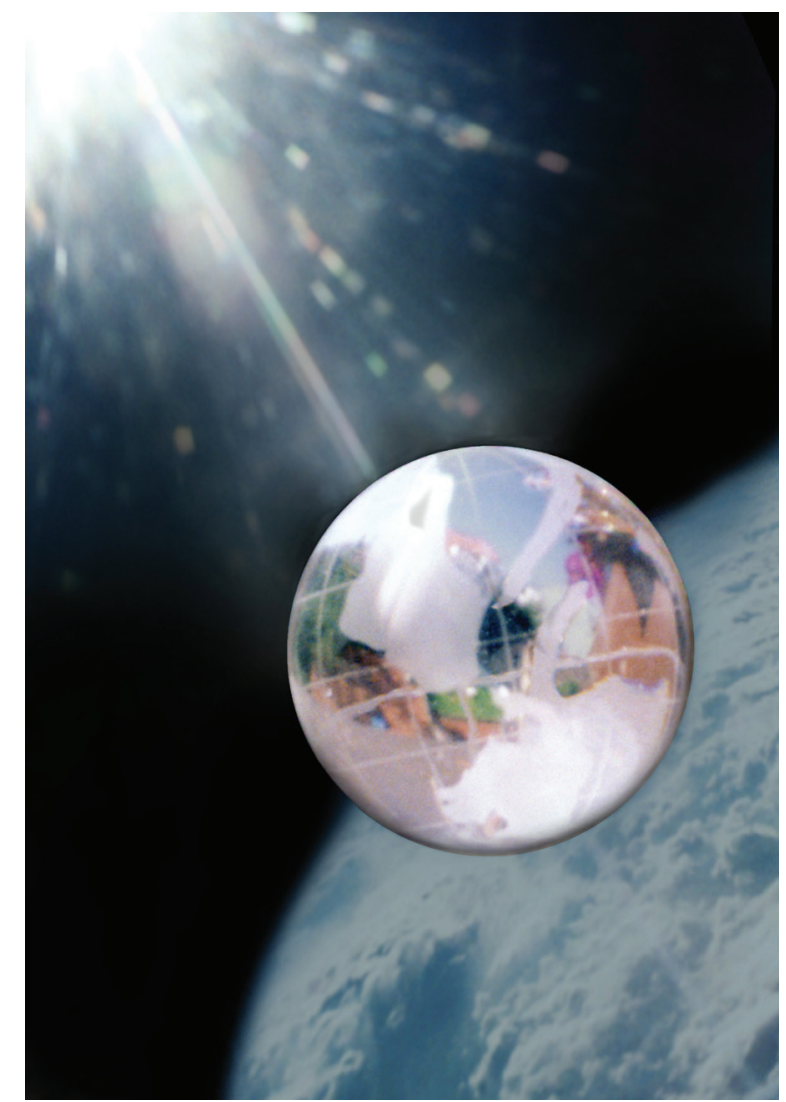

Figure 2. An imaginary planet with its moon.

extraterrestrials. If a star nearest to Earth, such as Proxima Centauri, would have an orbiting planet with living creatures, it would take us dozen thousands of calendar years to reach them by spaceship. Moreover, our radio messages sent to them would travel at least 4 years, and their response would be received on Earth for another 4 years.

\section{THE HUMAN MIND}

The Homo sapiens seems to be the greatest achievement of known nature, as presented metaphorically on the Dali's canvas "Geopolitical Child Watching the Birth of the New Man" (Fig. 3). The human evolution also inspired Piet Mondrian to depict a triptych of the same name (the "Evolution") in a dominant blue paint of human figures [11, 45]. The physicist Clerk Maxwell made a poetic comment on our development:

"So, down through untold generations,

transmission of structural germs

Enables our race to inherit the thoughts of beasts, fishes and worms."

And, he was undoubtedly right! Modern embryology and genetics have confirmed that we are not only 


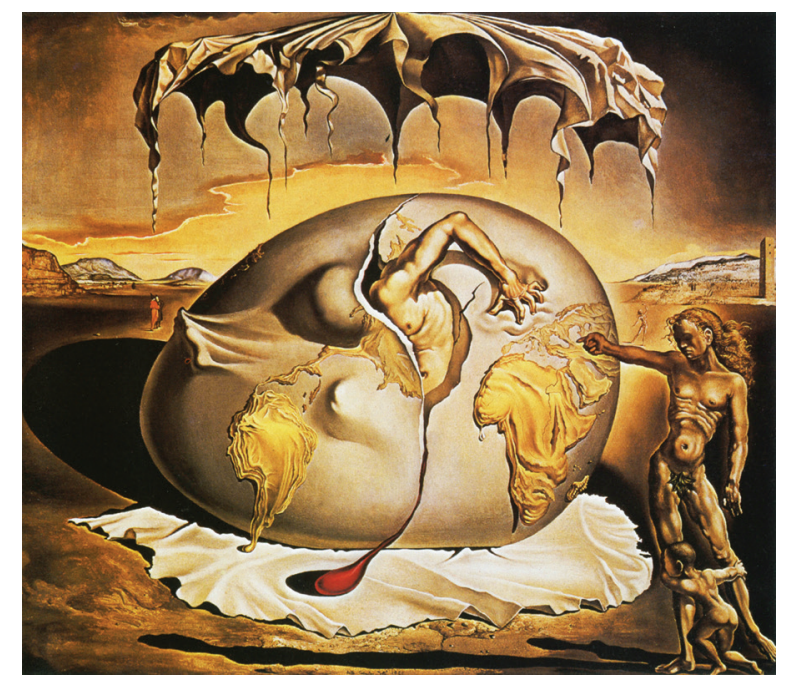

Figure 3. The painting by Salvador Dalí entitled "Geopolitical Child Watching the Birth of the New Man" (Credit: tfranks@FineArtRegistry.com).

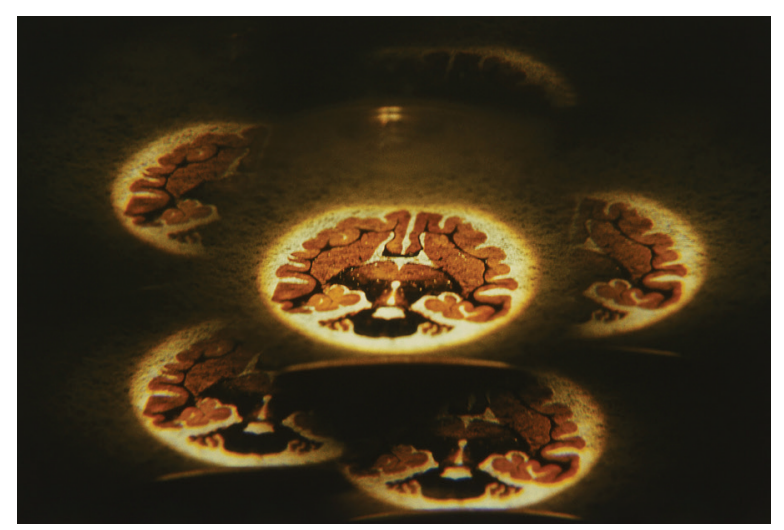

Figure 4. An axial section (multiplied) of the monkey brain.

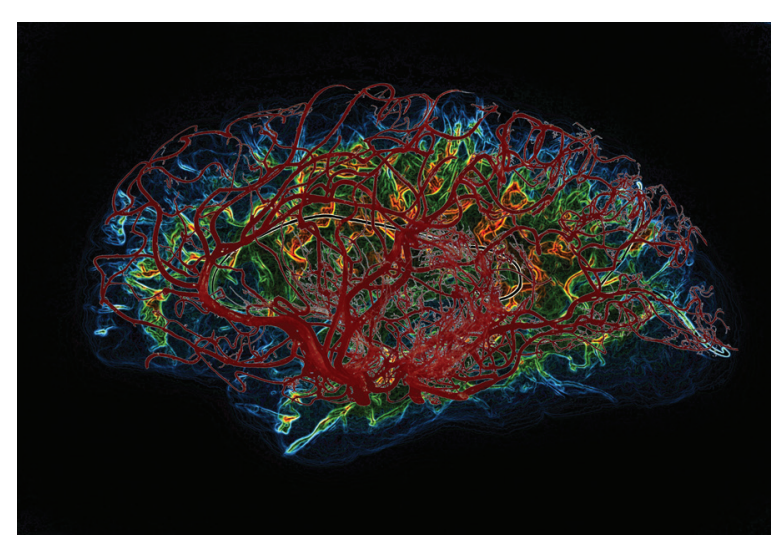

Figure 5. The human mind. (A photoshopped left cerebral hemisphere with superimposed brain arteries). segmented like worms and some other animals in our early embryonic development, but we also have in our genome some genes very similar to certain genes of yeasts, worms, and some insects and fishes [21, 38]. The remaining genes stem from other vertebrates, especially from mammals and our hominid ancestors. This explains why only about $2.5 \%$ of our genes are different from those in chimpanzees, including the genes responsible for the brain formation (Fig. 4). This also could be a biological basis for the archetypes and collective universal unconscious proposed by psychologist Carl Gustav Jung, which have probably influenced general human behaviour for many millennia [25], as well as a partial explanation of a modern theory of global consciousness.

The human brain (Fig. 5), especially its cortex, is a masterpiece of nature and the most complex organisation of matter in the known universe [31]. The stars in this micro-cosmos are neurons (Fig. 1), about 100 billions in number (surrounded by 3 times more glia cells), with their axons and dendrites interconnected by quadrillions of synapses, with hundreds of neurotransmitters and neuropeptides, and the innumerous specific membrane receptors [26]. Their forces, produced by the activity of many billions of ion channels, comprise electric forces, i.e. the rest and action potentials, depolarisation, and the excitatory and inhibitory postsynaptic potentials, in addition to the ever existing universal nuclear forces. The brain also shows a dialectic duality: positive-negative charges, excitation-inhibition, synthesis-degradation, survival-apoptosis. Several modern authors, such as Constance Jacobson, Geoffrey Koetsch, Denise Dumas and Mary Kaye, artistically presented the neural network and the brain itself [30].

Such an incredibly complex structure gave rise to a new and fascinating quality: consciousness, perception, thought, intelligence, memory, imagination, emotions, speech, social behaviour, etc. [3, 31, 33]. However, it was a long road from our ancestors to modern man to develop the present cognitive abilities. First of all, rational, logical and completely abstract thought had to replace gradually primordial magic and animistic thought, including belief in the soul, the afterlife, demons, divinities and gods, as well as faith in mythological and theological cosmogony and anthropogony attributing to some of those supernatural or transcendental beings and phenomena $[16,37]$. 
Modern intellectual thinking started in Mesopotamian and Mediterranean civilisations several thousands of years ago. Thanks to that, Leucippes and Democritus of the 5th century BCE could develop the atomic theory of the universe, which implied an infinite number of the invisible, uncaused, eternal and movable indivisible particles (Gr. atomon), which was the first unifying theory of the structure and organisation of the world, replacing the previous 4 element theory (earth, air, water and fire) of Empedocles [7].

This idea about a constant motion of atoms is in accordance with their predecessor Heraclitus (and later Buddhists) who believed in the dynamics and constant changes in the world based on the connection between opposites, which was later illustrated by the famous aphorism "panta rei" (everything flows) which came from the Neoplatonist Simplicius. Inspired by the atomistic theory, the Roman poet and philosopher Titus Lucretius wrote the poem "De rerum natura" (On the nature of things) [34].

A pleiad of scientists, especially in the last 130 years, e.g. Thompson, Planck, Rutherford, Chadwick and Bohr, proposed new models of the "indivisible" atom based on its structure, i.e. the subatomic particles in its nucleus and the orbiting electrons, thus founding quantum physics [10]. Similarly, the ingenious minds in ancient times, e.g. Selencus of Babylon, Clement of Alexandria, Heraclides Ponticus and Hipparchus of Nicaea, and those from the Renaissance to modern times, such as Galileo, Copernicus, Kepler, Brahe, Newton, Halley, Hubble, Einstein, Hawking and many others, completed our present knowledge of the material universe [42].

At the same time, however, Greek philosophers and ensuing thinkers have never stopped seeking the essence of the soul (Gr. pneuma; Lat. anima) and spirit, as shown in the philosophy of Socrates, Plato and Aristotle, in the writings of Galen, and later on in the work of Leonardo da Vinci, René Descartes, Hegel, the modern psychologist Carl Gustav Jung, the writers Leo Tolstoy and Fyodor Dostoyevsky, and many others $[8,9,12,14,25,44]$. The human being obviously cannot exist psychologically without a spiritual and irrational world, because it makes him sublime, offers hope, and implies the eternal.

The human privilege of thought-producing inspired French philosopher and mathematician René Descartes to state "Cogito, ergo sum" (I think, therefore I am), his compatriot August Rodin to create the grandiose bronze figure "The Thinker" and a tender sculpture "Thought" in white marble, the Ukrainian poet Shevchenko to write the poem under the same name ("My Thoughts"), and modern Italian musician Giuliano Poles to compose "Beyond the Thoughts" $[8,19]$. Similarly, Salvador Dalí made the surrealistic drawing "The Thinking Machine", Luigi Di Castro created the "Mind", whereas some artists founded conceptual art [13, 35]. Moreover, neuropsychologists and neuroradiologists can now "paint" someone's thoughts in the prefrontal cortex of the brain on the images of functional magnetic resonance (fMRI) as well as positron emission tomography (PET) [46]. Fortunately, no one can still decode or read them, so that they are still an intimate, secrete and privileged domain of our personality. But, for how long? Until scientists reveal in which way our materialistic neurons create abstract cognitive phenomena [32].

\section{SCIENCE AND ART}

Nature acts according to its own laws which are constant and universal, and which enable it an unthinkable power, especially regarding supernovae and black holes which can destroy the nearby portions of their galaxies [42]. On the other hand, the unlimited capabilities of the human mind have enabled a fascinating creativity, including scientific research and artwork production. Due to that, scientists discover the secrets of nature, but also create new phenomena and devices which cannot be produced by nature. Artists in turn subjectively present nature in their works of art, but also their own mental world never seen in nature.

The spiritus movens in science and art is primarily exploration, which is an evolutionary product [4]. Animals explore their environment to find food and water sources, a shelter or a mate, to identify the possible predators, to establish their own territory simply, to survive. The human brain, however, shows a great curiosity and need to explore the unknown, to acquire new knowledge, to find solutions and new ways, to change and create, and thus to satisfy his self-confirmation and to provide a hedonistic and, sometimes, even an ecstatic experience, like the anecdotal "Heurēka!" (I have found it!) shouted out by distinguished mathematician and innovator Archimedes [31].

In addition to examining the structure of atoms, the universe, DNA, etc., the perception ability and thinking qualities of the scientific mind are sometimes engaged in the explanation of the "simplest" everyday 
processes and phenomena observed by all people. Thus, from the origin of the mankind (and before) to the 17th century (and beyond), ripe apples used to fall onto the ground or, unfortunately, onto someone's head, but no one asked the question "Why?" apart from the ingenious physicist and mathematician Isaac Newton, who gave us an answer based on his revolutionary enlightenment: "Due to universal gravitational force" [10].

Similarly, millions of parents in the past millennia have witnessed their children manipulating and playing with their own mouth, genitals and excrement, but only Sigmund Freud realised that such behaviour is quite a normal and necessary psychosexual development in early childhood. On this basis Freud developed his revolutionary theory of the 3 levels of our personality, the ego, super-ego and id, whose psychodynamic interaction determines behaviour in adulthood $[17,27]$. This theory introduced psychoanalysis into selected patients' therapy, and inspired Andre Breton, Salvador Dalí and other surrealists to connect conscious and subconscious activity in their artworks [13].

A scientist is usually engaged in a specific problem in a limited field of research, where he or she is trying to find a definite answer and, eventually, universal truth. There are 2 main subjects of exploration, nature and life, including the human personality and society. However, the brain of a scientist also has another ability: to explore and create in domains which are not present in nature: philosophy, mathematics, cybernetics, nanotechnology, and similar mental achievements and sophisticated products.

The brain of a highly creative individual can perfectly function even when losing a connection with its own body. The ingenious mind of quadriplegic Stephen Hawking did not need his body and spinal cord, affected by the amyotrophic lateral sclerosis, to establish the greatest discoveries in theoretical astrophysics. Similarly to scientists, the brain of an artist functions properly even when void of perception. The ancient Greek poet Homer of the 8th century $B C E$, who was said to be blind, created 2 masterpieces, the "Iliad" and the "Odyssey". Ludwig van Beethoven wrote the "Ninth Symphony" in the silence of his complete deafness. The "mind ear" in his temporal and prefrontal cortices composed and listened to the music like our brain often uses inner speech and internal mental images for thinking and imagination.
An artist also explores nature, people and himself, thanks to his abstract thinking, curiosity and high perceptive abilities, with the aim, among others, to find an inspiration for his creative work [48]. However, inspiration and ideas often are his purest mental products, based on his previous experience, imagery and fantasy, intuition, emotions, aesthetic sensibility, and a desire for innovation, i.e. for a new sound and harmony in music, and a new pattern and style in visual art, which is especially expressed in the phantasmagoric, symbolistic, abstract, dadaistic and surrealist creations of Fuseli, Moreau, Redon, Ernst, Miro, Kandinsky, Duchamp, Dalí, Magritte, Debussy, Xenakis and others $[11,13,18]$. Nevertheless, creating a painting, sculpture, novel, poem or a musical composition, is a necessity for his psychological integrity and it is associated with a great emotional experience and a reward for his cortical and subcortical hedonistic zones [31].

There is often a situation that a scientist from one cycle of research immediately enters another one, and then still another, and so on. This is what we call a "discovery addiction", a research spiral, a chain reaction with no end. Unlike a scientist, however, an artist has virtually unlimited possibilities and an endless freedom in creativity but, like a scientist, he also expresses a great lust for creation. He is trying to perceive his own truth of the world and to provoke feelings and imagery in art lovers [48]. Hence, the plays of Aristophanes, Sophocles and Shakespeare lead us to exaltation or tears, whereas "Toccata and Fugue in D minor" by Bach, "The Piano Concerto in C major" by Mozart and in "C minor" by Rachmaninoff, "The Fifth Symphony" by Beethoven, "Götterdämmerung" by Wagner, and many other masterpieces written by famous composers, lift us to the cosmic heights.

Music, and art in general, have a beneficial effect on the cognitive functions of the listeners and spectators, particularly on the brain regions for generating, recognising and regulating emotions, e.g. the anterior cingulate cortex, orbitofronal, dorsolateral and ventrolateral prefrontal cortices [39]. This is why modern psychiatrists apply art therapy for their patients' treatment.

Art is mostly based on subjectivism, sensibility, emotions and passion, and science on rationality, reason, precision, and patience. But they both use, although in a somewhat different manner and intensity, the same cognitive processes, and experience the same level of exaltation. For that reason, 
the artistic and scientific creativities share the same pattern and reach the same point: a discovery, or a new work of art.

Moreover, there is even an overlapping and merging of art and science [28]. For instance, as far back as some 2,500 years ago, the Greek thinker Pythagoras introduced certain mathematical principles into music [7]. Many centuries later, the work of the renaissance genius Leonardo da Vinci became both art and science [49]. The 18th century English surgeon Charles Bell was an artist as well, Russian Anton Chekhov of the 19th century was a physician and famous writer, modern novelists Simon Mawer and Alan Lightman are experts in biology and physics, respectively, whereas Brian May was a member of the famous rock group Queen, but also an astrophysicist $[6,12]$. The impressionists Georges Seurat and Paul Signac applied a new scientific colour theory in their "pointillist" painting [40, 47]. René Magritte painted the "Golconde" (Fig. 6A) with male figures seem to be falling like drops of rain in a vertical and horizontal arrangement, which is exactly the same pattern as the laminar and columnar organisation of the cerebral neocortex (Fig. 6B), as was described by Cajal, Brodmann, Golgi, Hubel, Wiesel and others [2, 5, 36]. The English contemporary artist Richard Deacon made several sculptures and installations resembling the DNA molecule, whereas Marc Quinn even used a culture from a scientist DNA to present his "portrait" [29]. Artist McMullen, inspired by quantum physics, created the artwork "Skin without Skin".

Modern musicians apply electronics to compose or play music, while contemporary visual artists express themselves in computer graphics or digital art, thus using machines and software created by scientists. On the other hand, some science-fiction writers gave new ideas and even predicted future discoveries. Sir Arthur Clarke, for instance, envisioned a communications satellite system two decades before its scientific and technical realisation. Yet, contemporary research seems to surpass science fiction ideas and imagery.

The brain of ingenious individuals shows some supreme abilities: better processing of information, generating more possible solutions, thinking in terms of analogies and a variety of associations, considering a problem or an idea from a number of different aspects and analysing each of them through a series of steps, presenting rich and productive imagery, and having flexible mental operations [31]. The neuro-
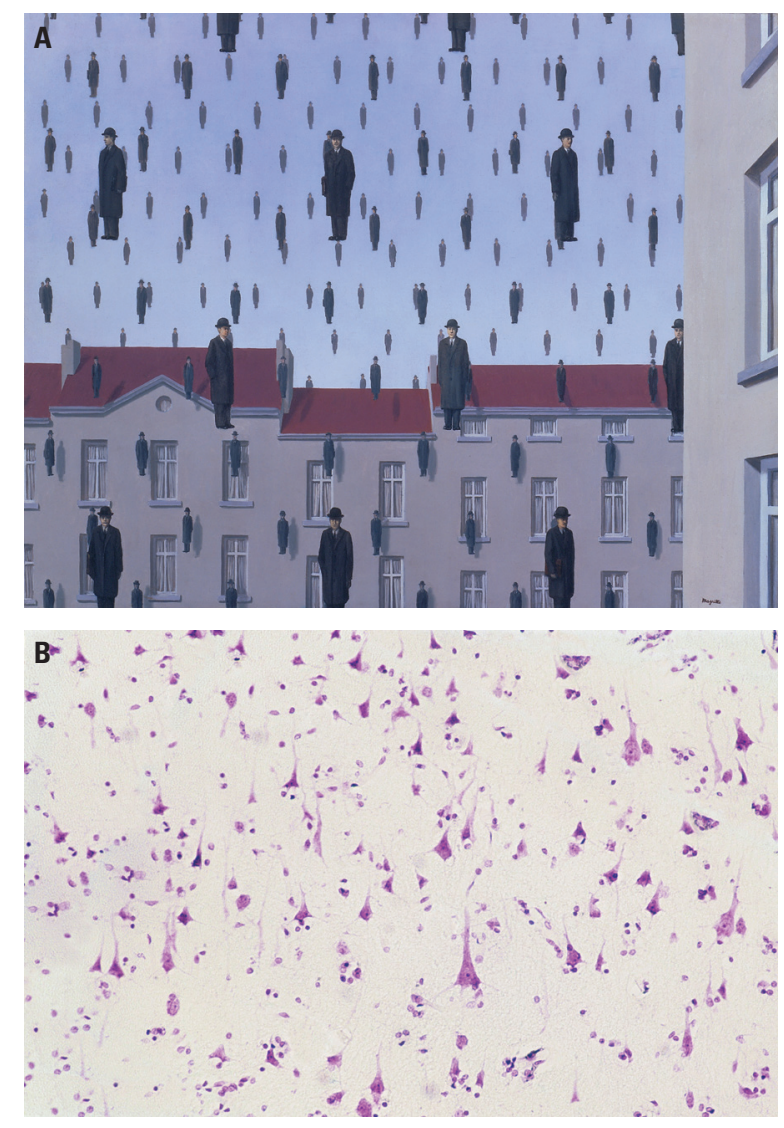

Figure 6. A. The painting "Golconde" by René Magritte (Credit: The Menil Collection, Houston. Photographer: Hickey Robertson, Houston); B. Horizontal and vertical arrangement of the cortical neurons (following cresyl violet staining).

anatomical basis for such abilities is, among others, a larger volume of certain cortical areas due to a larger number of the synapses and their functional potentials. For instance, Einstein's brain had a larger cortical surface and a larger number of the supporting (glia) cells in the parietal lobe, a region which is responsible for mathematics and visuospatial abilities [31].

This is why ingenious individuals make revolutionary achievements and change of the previous views of the world, and why artist Diego Rivera painted the mural "Man, Controller of the Universe" [33]. As already noticed, it was believed from the time of Leucippes and Democritus that the atom is an indivisible unit. Yet, about 2,400 years later, the previously mentioned scientists discovered the electron, proton and neutron, respectively, that is, the first subatomic particles, whose number nowadays exceeds 200. Newton discovered the universal gravity force, whereas Einstein came to a conclusion that the latter force, especially of large celestial objects, makes a certain deformation 
of space and time, causing even a light beam to bend - and he did this only by performing his "mental experimentation". The American astronomer Hubble revealed, by using the redshift measurements, that the universe is not a stationary system, but rather it expands progressively. In addition, a background microwave cosmic radiation was recently discovered, which confirmed the Big Bang theory [42].

Gregor Mendel determined the transmission of hereditary characteristics in successive generations of pea hybrid progeny, thus explaining how offspring can acquire the features of their parents and ancestors [21]. Charles Darwin proved that human beings are not the descendants of the biblical Adam and Eve, but they diverged from an ancestor shared with anthropoids, probably chimpanzees, some 6 million years ago [4]. Crick and Watson discovered the DNA structure and, in this way, the essence of life. Contemporary genetic engineering produces useful microorganisms, antibiotics, hormones and vaccines, and certain sorts of plants and animals with better traits. Gene therapy is starting a new era in medicine. In addition, a research team in Scotland produced in 1996 the cloned sheep Dolly, whereas scientists made recently a revolution using stem cells to replace damaged tissues and organs. Homo sapiens is obviously taking over the competence of nature itself.

A somewhat similar situation occurred in fine art. Pablo Picasso broke down a 40,000 years tradition of 3-dimensional art and created his 2-dimensional cubistic artworks. Vasily Kandinsky left figurative art to create his abstract painting. Dadaist Marcel Duchamp depicted a moustache onto a Mona Lisa reproduction, which was followed by Walter Serner's shouting: "Art is dead, long live Dada!" [11, 15, 22, 24]. Walter Gropius, El Corbusier, Lloyd Wright, Norman Foster, Santiago Calatrava and some other architects designed many futuristic buildings [20]. Composers Arnold Schönberg, and Claud Debussy to some extent, made a revolution in modern musical harmony by introducing dodecaphony, i.e. a technique giving an equal importance to all twelve tones of the chromatic scale. New harmony is expressed in the piece "Jardins sous la Pluie" by Debussy.

Art and science are developing and changing all the time, in accordance with an endless changes and modifications of nature. The antique Greek "panta rei", as a universal principle, never comes to its end.

\section{CONCLUSIONS}

The absolute unity of the human mind, living world, the Earth and cosmos, i.e. matter and energy, real and abstract, crude cosmic power and sophisticated life, creation and destruction, will exist almost for ever, that is, for another few billion years, until an unimaginable cataclysmic apocalypse. They all could then continue as a metaphorical reincarnation in an 11 th dimension, in a parallel universe, or in another world which will be born somewhere in endless and timeless non-space.

\section{ACKNOWLEDGEMENTS}

This work was supported by grant no. 175061 from the Ministry of Science, Serbia.

We are very grateful to Mrs. Elza Holt for reviewing the English text of our manuscript.

\section{REFERENCES}

1. Bernari C (1970) L'opera completa del Tintoretto. Rizzoli Editore, Milano. [In Italian].

2. Brodmann K (1909) Vergleichende Lokalisationlehre der Grosshirnrinde in ihren Prinzipien dargestellt auf Grund des Zellbaues. JA Barth, Leipzig [In German].

3. Brown GDA, Hocking I, Foster JK, Mattys SL, Milne SE, Nallan GB, Wills A (2005) Introducing Psychology. Thinking and knowing. Grange Books, Rochester.

4. Campbell NA, Reece JB, Mitchell LG, Taylor MR (2003) Biology. Concepts \& connections. Benjamin Cummings, San Francisco.

5. Carpenter MB (1991) Core text of neuroanatomy. Williams and Wilkins, Baltimore.

6. Chekhov A (2002) Ward No. 6 and other stories, 18921895. Penguin Books, London.

7. Copleston FSJ (1976) A history of philosophy. Greece and Rome. From the pre-Socratics to Plotinus. Vol. I. A.P. Watt \& Son, London.

8. Copleston FSJ (1976) A history of philosophy. Late mediaeval and renaissance philosophy. Ockham to Suarez. Vol. III. A.P. Watt \& Son, London.

9. Copleston FSJ (1976) A history of philosophy. Modern philosophy. The British philosophers. Vol. V. A.P. Watt \& Son, London.

10. Cutnell JD, Kenneth JW (2007) Physics. 7th Ed. John Wiley \& Sons, Inc., New York.

11. Davies PJE, Denny WB, Hofrichter FF, Jacobs J, Roberts AM, Simon DL (2007) Janson's history of art. The Western tradition. Pearson Prentice Hall, Upper Saddle River.

12. Del Maestro RF (1998) Historical vignette. Leonardo da Vinci: the search for the soul. J Neurosurg, 89: 874-887.

13. Descharnes R, Néret G (2006) Salvador Dalí. Taschen, Köln.

14. Dostoyevsky F (2008) The brothers Karamazov. Dover Publications, New York.

15. Elger D (2006) Dadaism. Taschen, Köln.

16. Eliade M (1988) The encyclopaedia of religion. MacMillan Publishing, New York. 
17. Freud S (1907) Zur Psychopathologie des Alltagslebens. Verlag von S. Karger, Berlin [In German].

18. Gibson M (2006) Symbolism. Taschen, Köln.

19. Goldscheider $L$ (1979) Rodin sculptures. Phaidon, Oxford.

20. Gössel P, Leuthäuser G (2005) Architecture in the 20th century. Taschen, Köln.

21. Griffiths AJF, Miller JH, Suzuki DT, Lewontin RC, Gelbart WM (2000) An introduction to genetic analysis. 7th Ed. W.H. Freeman \& Company, New York.

22. Guerman M (2004) Vasily Kandinsky. Grange Books, Rochester.

23. Guirnad F, Schmidt J (1996) Mythes \& mythologie. Historie et dictionnaire. Larouse, Paris [In French].

24. Jaffé HLC (1988) Pablo Picasso.Thames and Huston, Ltd., London.

25. Jung $C$ (1990) The archetypes and the collective unconscious. 10th Ed. Princeton University Press, Princeton, New Jersey.

26. Kandel ER (2000) The neurobiology of behavior. In: Principles of neural science. McGraw-Hill, Health Professions Division, New York, pp. 5-18.

27. Kaplan HJ, Sadock BJ (2003) The brain and behavior. In: Kaplan Sadock's synopsis of psychiatry, behavioral sciences/ clinical psychiatry. Lippincott Williams \& Wilkins, a Walters Kluwer Company, Philadelphia, pp. 66-135.

28. Kemp M (2000) Visualizations. The nature book of art and science. Oxford University Press, Oxford.

29. Kemp M (2005) From science in art to the art of science. Nature, 434: 308-309.

30. Koetsch G (2011) Artists and the mind in the 21 th century. Front Human Neurosci, 5: 1-8.

31. Kosslyn SM, Rosenberg RS (2004) Psychology. The brain, the person, the world. Pearson Education, Inc., Boston.

32. Libet $B$ (2006) Reflections on the interaction of the mind and brain. Prog Neurobiol, 78: 322-326.
33. Lozano LM, Rivera JRC (2005) Diego Rivera. The complete murals. Taschen, Köln.

34. Lucretius T (1853) On the nature of things. Henry G. Bohn, London.

35. Marzona D (2006) Conceptual art. Taschen, Köln.

36. Meuris J (2007) René Magritte. Taschen, Köln.

37. Néret G (2003) Devils. Taschen, Köln.

38. O’Rahilly R, Müller F (2001) Human embryology and teratology. Wiley-Liss, A. John Wiley and Sons, Inc., Publications, New York.

39. Rosen HJ, Levenson RW (2009) The emotional brain: combining insights from patients and basic science. Neurocase, 15: 173-181.

40. Ruhrberg K, Schneckenburger S, Fricke M, Honnef K (2005) Art of 20th century. Painting, sculpture, new media, photography. Taschen, Köln.

41. Shakespeare W (1999) The complete works. Wordsworth Editions Limited, London.

42. Spence P (2002) The universe revealed. Chancellor Press, London.

43. Sutton C (2011) Subatomic particles. Encyclopaedia Britannica, London.

44. Tolstoy L (2002) Anna Karenina. Signet Classics, New York.

45. Tosi B (1975) I classici della pittura. Mondrian. Armando Curcio editore, Roma [In Italian].

46. van Heertum RL, Tikofsky RS, Ichise M (2010) Functional cerebral SPECT and PET imaging, 4th ed. Wolters Kluwer, Lippincott Williams \&Wilkins, Philadelphia.

47. Walther JF (2006) Impressionism. Taschen, Köln.

48. Zeki S (2001) Artistic creativity and the brain. Science, 293: 51-52.

49. Zöllner F (2007) Leonardo da Vinci. The complete paintings and drawings. Taschen, Köln.. 